\title{
Geneza równin torfowiskowych w dolinach rzecznych dorzecza górnej Odry
}

\author{
The origin of peatland plains in the river valleys of the Upper Odra Basin
}

\section{Krzysztof Jan Wójcicki}

Katedra Rekonstrukcji Środowiska Geograficznego, Wydziat Nauk o Ziemi, Uniwersytet Śląsi, Sosnowiec krzysztof.wojcicki@us.edu.pl

\begin{abstract}
Zarys treści: Artykuł poświęcony jest problematyce genezy równin torfowiskowych w strefie „staroglacjalnej” południowej Polski. W objętych badaniami dolinach Kłodnicy i Osobłogi, torfowiska rozwinęły się głównie w obniżeniach starorzeczy. Akumulacja biogeniczna została zainicjowana w różnych fazach późnego glacjału i holocenu, w szczególności w młodszym dryasie i okresie preborealnym w przypadku form położonych u podnóży zboczy doliny, oraz w fazie subborealnej i subatlantyckiej w przypadku mniej licznych form zlokalizowanych w strefie proksymalnej równiny zalewowej. W dolinie Kłodnicy zostały zidentyfikowane następujące etapy rozwoju form akumulacji biogenicznej: (1) szybki przyrost osadów we wczesnym i prawdopodobnie środkowym holocenie, (2) ograniczenie tempa akumulacji u schyłku mezoholocenu(?) i w starszym neoholocenie, (3) ponowny wzrost tempa akumulacji osadów w młodszej części późnego holocenu. Rozwój większości form akumulacji biogenicznej został zatrzymany w ostatnim tysiącleciu na skutek antropogenicznego ożywienia procesów fluwialnych i denudacyjnych.
\end{abstract}

Słowa kluczowe: biogeomorfologia, formy biogeniczne, starorzecza, geneza torfowisk, paludyfikacja, Kotlina Raciborska

\begin{abstract}
The article discusses the origin of peatland plains in the 'old glacial' zone of southern Poland. In the studied valleys of the Kłodnica and Osobłoga Rivers, peatlands developed mainly in the depressions of oxbow lakes. Biogenic accumulation started in various periods of the Late Glacial and Holocene, particularly in the Younger Dryas and Preboreal phases in the case of forms at the foot of the valley sides, and in the Subboreal and Subatlantic phases in the case of less numerous forms within proximal floodplain. The following development stages of floodplain fens were identified in the Kłodnica valley: (1) the rapid growth of deposits in the Early and possibly in the Middle Holocene, (2) significant reduction in the accumulation rate at the end of the Middle Holocene (?) and in the earlier part of the Late Holocene, (3) the re-growth of sediment accumulation rate in the later part of the Late Holocene. Development of numerous biogenic landforms has been stopped as a result of human-induced acceleration of fluvial and denudation processes in the last millennium.
\end{abstract}

Key words: biogeomorphology, biogenic landforms, oxbow lakes, peatland origin, paludification, Racibórz Basin

\section{Wstęp}

Pochodzenie rozległych równin akumulacji biogenicznej w dolinach strefy „młodoglacjalnej” było na ziemiach polskich przedmiotem licznych badań, wśród których można wymienić prekursorskie opracowania Małkowskiego (1930), Krygowskiego (1936) oraz Kulczyńskiego (1939/40). Według syntetycznego schematu Żurka (1975), późnoglacjalny etap przygotowawczy do zatorfienia dolin w północno-wschodniej Polsce polegał na wy- tworzeniu lokalnych zagłębień wskutek wytapiania lodu gruntowego, deflacji i akumulacji eolicznej oraz progradacji stożków napływowych. W holocenie, przy sprzyjających warunkach hydroklimatycznych mogło dojść do całkowitego zatorfienia dolin, czemu sprzyjało dalsze modelowanie rzeźby równiny zalewowej (w szczególności powstawanie starorzeczy i basenów powodziowych ograniczonych wałami przykorytowymi). Zagadnienie genezy form akumulacji biogenicznej w dolinach rzecznych strefy „staroglacjalnej” nie doczekało się podobnej 
syntezy. Co prawda, w pracach z dorzecza górnej Wisły znajdujemy liczne opisy osadów biogenicznych (zwykle facji starorzecznej), ale były one wykorzystywane jako narzędzie do rozwiązania problemów z zakresu geologii czwartorzędu i geomorfologii fluwialnej (m.in. Alexandrowicz i in. 1981, Starkel 2001, Gębica 2004, Kalicki 2006), paleobotaniki (m.in. Szczepanek 1982, Nalepka 1991), czy archeologii środowiskowej (Wasylikowa $\mathrm{i}$ in. 1985). Również w dorzeczu górnej Odry, badania osadów biogenicznych były prowadzone w kontekście historii roślinności (m.in. Schubert 1930, Nita, Wójcicki 2005, Wójcicki, Kloss 2008, Wójcicki 2013) oraz rekonstrukcji holoceńskich procesów fluwialnych i denudacyjnych ze szczególnym uwzględnieniem wpływu kultur rolniczych na natężenie erozji gleb (m.in. Klimek 1996, 2003, Zygmunt 2004, Wójcicki 2006, Wójcicki, Marynowski 2012). Realizacja wymienionych projektów badawczych przyczyniła się do rozpoznania budowy dolin na tyle, by można było podjąć problematykę pochodzenia zbiorników akumulacji biogenicznej w dorzeczu górnej Odry. Niniejsza publikacja ma na celu zestawienie wyników wieloletnich studiów, których pośrednim efektem była inwentaryzacja i określenie uwarunkowań rozwoju form akumulacji biogenicznej w Kotlinie Raciborskiej.

\section{Obszar i metody badań}

Rzeźba „staroglacjalna” charakteryzująca się brakiem zagłębień bezodpływowych nie sprzyja akumulacji biogenicznej. Według danych Systemu Informacji Przestrzennej o Mokradłach Polski (2006) w granicach Kotliny Raciborskiej występuje jedynie 30 torfowisk, z których aż 27 położone jest w dolinach rzecznych. Opierając się na tych danych można wyliczyć, że łączna powierzchnia równin akumulacji biogenicznej w Kotlinie Raciborskiej wynosi około 1340 ha, co stanowi 1,1\% powierzchni mezoregionu. Liczba ta jest nieco zaniżona, gdyż nie uwzględnia m.in. blisko 30 niewielkich (zazwyczaj poniżej 10 ha) mokradeł dolinnych ujawnionych w trakcie badań w dolinach Odry, Rudy, Kłodnicy i Osobłogi (Wójcicki 2006, 2010, 2012, 2013). Do szczegółowych badań nad genezą równin akumulacji organicznej zostały wytypowane dolne odcinki doliny Kłodnicy oraz Osobłogi reprezentujące średniej wielkości, piaskodenne rzeki kręte (Ryc. 1). W dolinach tych brak jest większych torfowisk, co jest cechą typową dla całego mezoregionu Kotliny Raciborskiej.

Do form akumulacji biogenicznej w niniejszym opracowaniu zaliczone zostały współczesne i kopalne zbiorniki biogeniczne, w których zgodnie $\mathrm{z}$ definicją stosowaną w torfoznawstwie zgromadzone zostały osady organiczne o miąższości ponad 0,3 m (Ilnicki 2002). W efekcie, pominięte zostały charakterystyczne dla krajobrazu ostatnich dziesięcioleci obniżenia poeksploatacyjne, co prawda zajęte przez ekosystemy torfotwórcze (Wójcicki 2010), ale nie spełniające kryterium minimalnej miąższości zgromadzonych w nich osadów. Identyfikacja równin akumulacji biogenicznej w badanych odcinkach dolin została poprzedzona analizą wielkoskalowych map topograficznych i zdjęć lotniczych. Wyznaczony w ten sposób zasięg występowania osadów organicznych został zweryfikowany w trakcie terenowych wierceń geologicznych. Genezę zbiorników wypełnionych osadami organicznymi ustalono w oparciu o analizę rzeźby i interpretację przekrojów geologicznych. Chronologię akumulacji biogenicznej określono na podstawie wyników analizy pyłko-

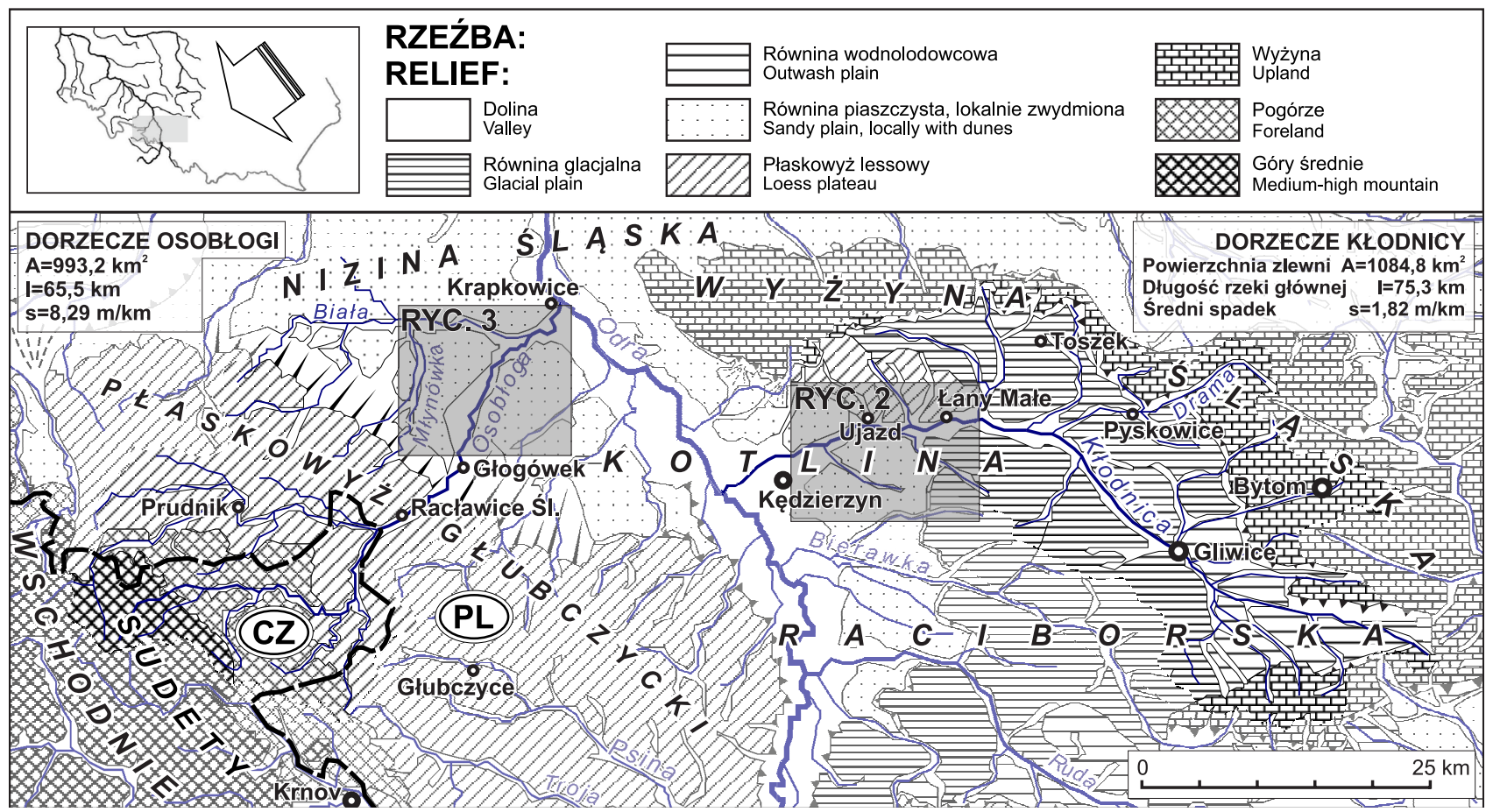

Ryc. 1. Lokalizacja obszaru badań na tle jednostek geomorfologicznych dorzecza górnej Odry

Fig. 1. Location of the study area on the map of geomorphological units of the Upper Odra basin 
wej (Nita, Wójcicki 2005) oraz datowań bezwzględnych wykonanych w laboratoriach radiowęglowych w Gliwicach, Kijowie, Poznaniu oraz Skale.

\section{Wyniki}

\section{Formy akumulacji biogenicznej w dolinie dolnej Kłodnicy}

Badaniami objęto równoleżnikowy odcinek dna doliny pomiędzy Pławniowicami, a Blachownią Śląską obejmujący obszar 1822,1 ha. Holoceńskie osady biogeniczne o miąższości przekraczającej $30 \mathrm{~cm}$ zostały zidentyfikowane na 17 stanowiskach (Ryc. 2) zajmujących łącznie 43,6 ha, co stanowi 2,39\% powierzchni dna doliny dolnej Kłodnicy. Zaledwie w 9 przypadkach osady biogeniczne przynajmniej częściowo ukazują się na powierzchni. W pozostałych stanowiskach występują pod cienką pokrywą neoholoceńskich aluwiów powodziowych, bądź deluwiów stokowych. Równiny akumulacji biogenicznej w dolinie dolnej Kłodnicy koncentrują się w dystalnej strefie dna doliny. W pasie przyzboczowym leży 12 stano- wisk obejmujących 95,6\% ogólnego areału zidentyfikowanych złóż torfu. Dla kontrastu, w strefie proksymalnej równiny aluwialnej zidentyfikowano jedynie 5 stanowisk, których osady zajmują zaledwie 4,4\% ogólnej powierzchni wystąpień osadów biogenicznych.

Pochodzenie osadów biogenicznych w dolinie dolnej Kłodnicy związane jest przede wszystkim ze starorzeczami. Osady tej genezy zajmują w sumie obszar 34,5 ha, tj. 79,1\% ogólnej powierzchni wystąpień osadów biogenicznych w dolinie dolnej Kłodnicy. Reszta przypada na osady dość rozległego torfowiska przyzboczowego w Łanach Małych oraz niewielkiego kopalnego zbiornika położonego w strefie przykorytowej Kłodnicy w miejscowości Huta Piła. O rozwoju torfowisk u podnóża stoków doliny zadecydowały zapewne dwie zasadnicze przyczyny. W późnym vistulianie i w początkach holocenu zostały tu uformowane rozległe depresje wielkopromiennych paleomeandrów Kłodnicy (Wójcicki 2006). Po drugie, stoki doliny Kłodnicy mają w wielu miejscach charakter stromych krawędzi erozyjnych o wysokości sięgającej kilkunastu metrów ponad dno doliny. Duże deniwelacje sprzyjają obfitym wysiękom wód gruntowych u podnóża stoków, zapewniając soligeniczny typ zasilania tworzącym się torfowiskom.
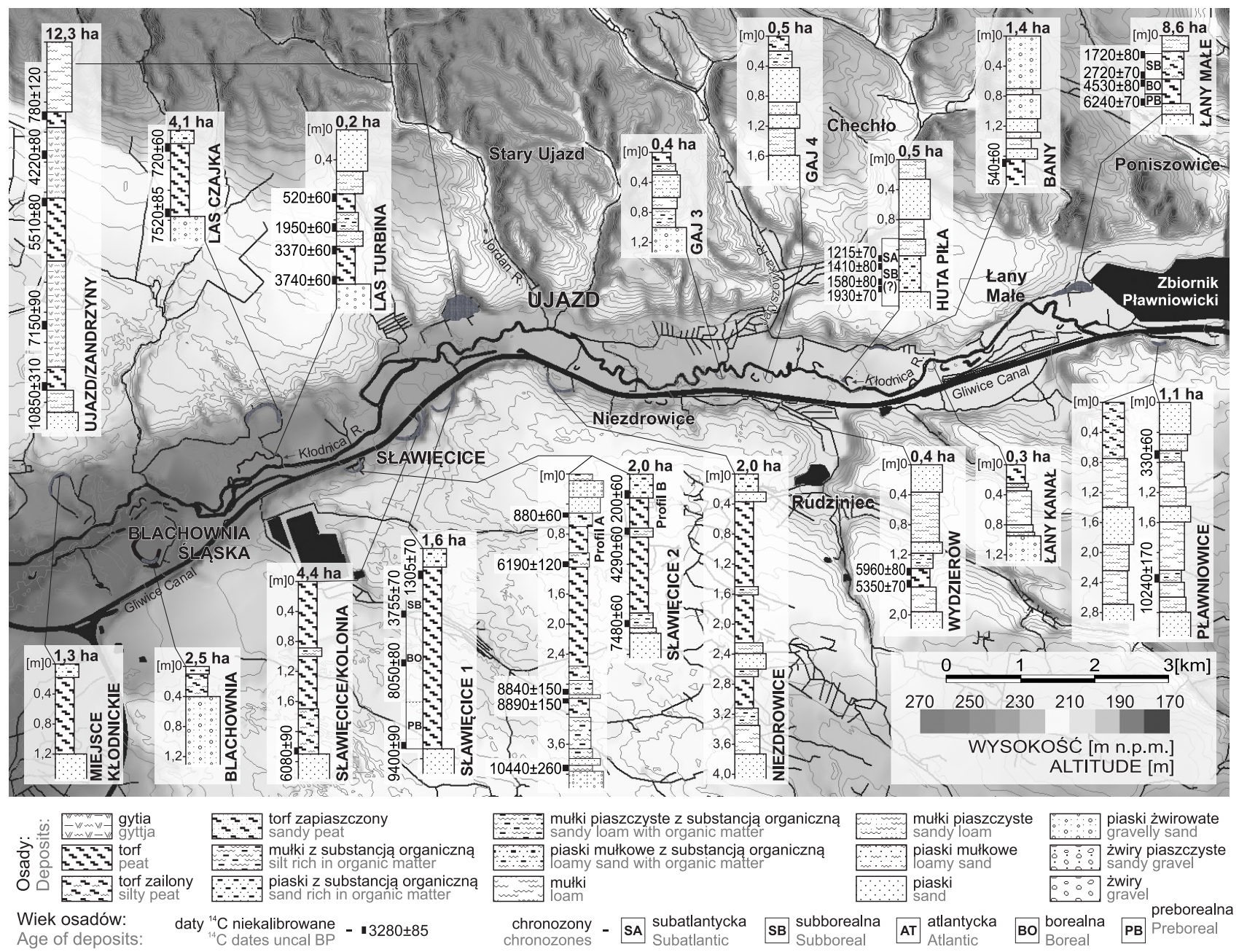

Ryc. 2. Rozmieszczenie i budowa wewnętrzna form akumulacji biogenicznej w dolinie dolnej Kłodnicy

Fig. 2. Location and internal structure of organic landforms in the Lower Kłodnica valley 


\section{Formy akumulacji organicznej w dolinie dolnej Osobłogi}

Badaniami objęto dno doliny pomiędzy Głogówkiem, a ujściem Osobłogi do Odry w Krapkowicach. Na odcinku tym zajmującym obszar 2290,8 ha zidentyfikowano 12 stanowisk z holoceńskimi osadami biogenicznymi (Ryc. 3 ), występującymi na obszarze 20,8 ha. Tym samym równiny akumulacji organicznej zajmują $0,9 \%$ powierzchni dna doliny dolnej Osobłogi. W większości stanowisk osady biogeniczne występują pod cienką pokrywą neoholoceńskich aluwiów powodziowych lub deluwiów stokowych. Osady biogeniczne w dolinie dolnej Osobłogi występują głównie w dystalnej strefie dna doliny. U podnóża stoków w środkowym biegu doliny, oraz u podnóża krawędzi wyższej terasy plejstoceńskiej w dolnym biegu doliny zlokalizowanych jest 7 stanowisk obejmujących 92,2\% areału zidentyfikowanych złóż torfu. Z kolei $\mathrm{w}$ strefie proksymalnej równiny aluwialnej zidentyfikowano 5 stanowisk, których osady zajmują 7,8\% ogólnej powierzchni wystąpień osadów biogenicznych.

W świetle analizy kartograficznej i obserwacji terenowych, wszystkie zidentyfikowane złoża torfu z doliny środkowej i dolnej Osobłogi związane są z porzuconymi korytami rzecznymi. Przekroje geologiczne dowiodły bowiem, że nawet stosunkowo rozległe równiny akumulacji biogenicznej w stanowiskach Głogówek, Nowy Młyn, Żywocice oraz Krapkowice 1 powstały wskutek ekspansji torfowisk poza macierzyste obniżenia starorzeczy (Wójcicki 2013). O rozwoju torfowisk w dystalnej strefie równiny zalewowej zadecydowały zapewne podobne przyczyny, jak w dolinie Kłodnicy. Na przełomie późnego vistulianu i holocenu koryto Osobłogi podcinało prawobrzeżną krawędź doliny. W efekcie w południkowym odcinku doliny zaznacza się asymetria stoków. Największe torfowiska rozwinęły sie u podnóża stoków wschodnich - krótkich i stromych, w stanowisku Głogówek osiągających wysokość prawie $20 \mathrm{~m}$ ponad dno doliny.

\section{Dyskusja}

\section{Wiek inicjacji i ekspansji procesów akumulacji biogenicznej}

Rezultaty datowań bezwzględnych osadów fazy inicjalnej z największych, podstokowych form akumulacji bio-

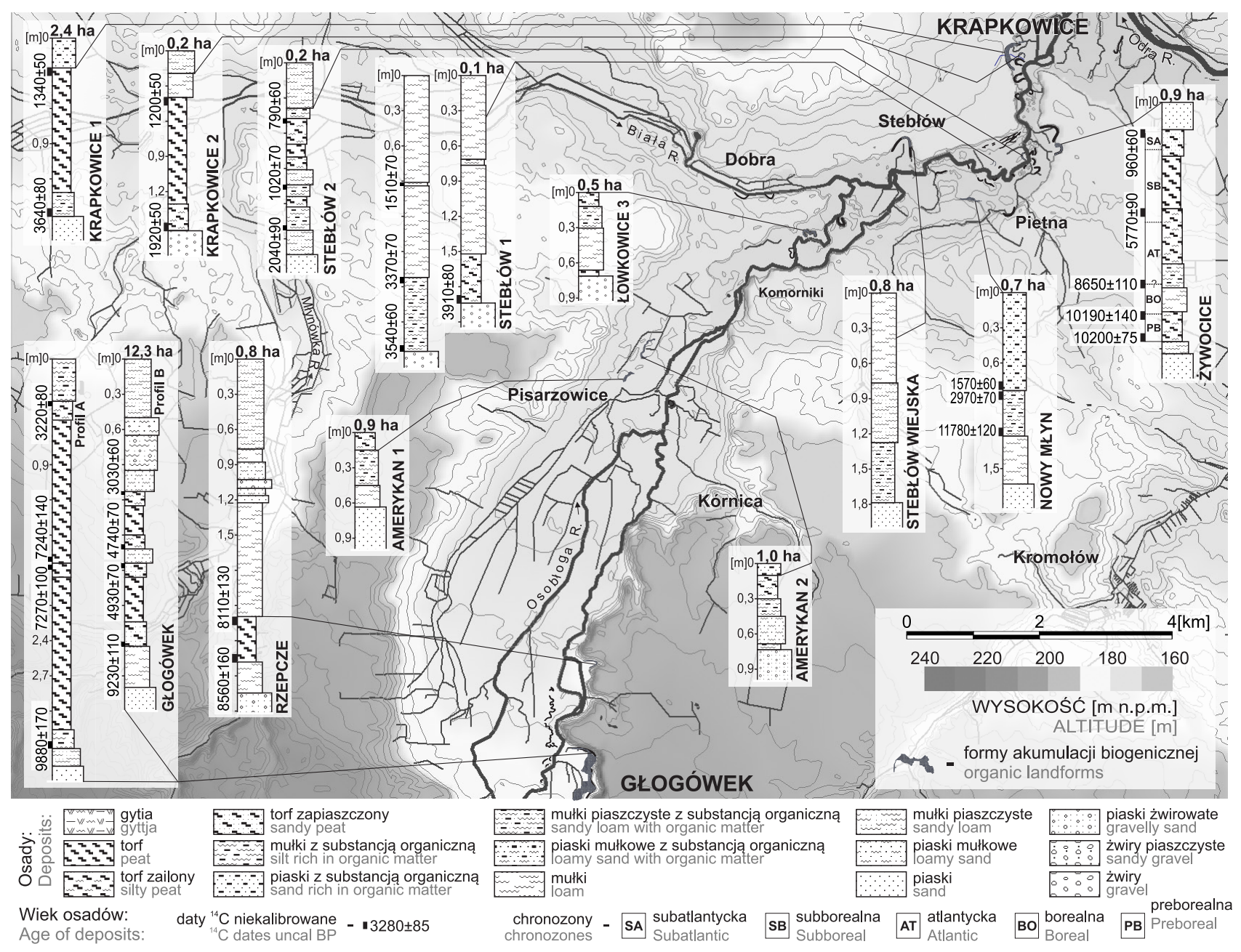

Ryc. 3. Rozmieszczenie i budowa wewnętrzna form akumulacji biogenicznej w dolinie dolnej Osobłogi

Fig. 3. Location and internal structure of organic landforms in the Lower Osobłoga valley 


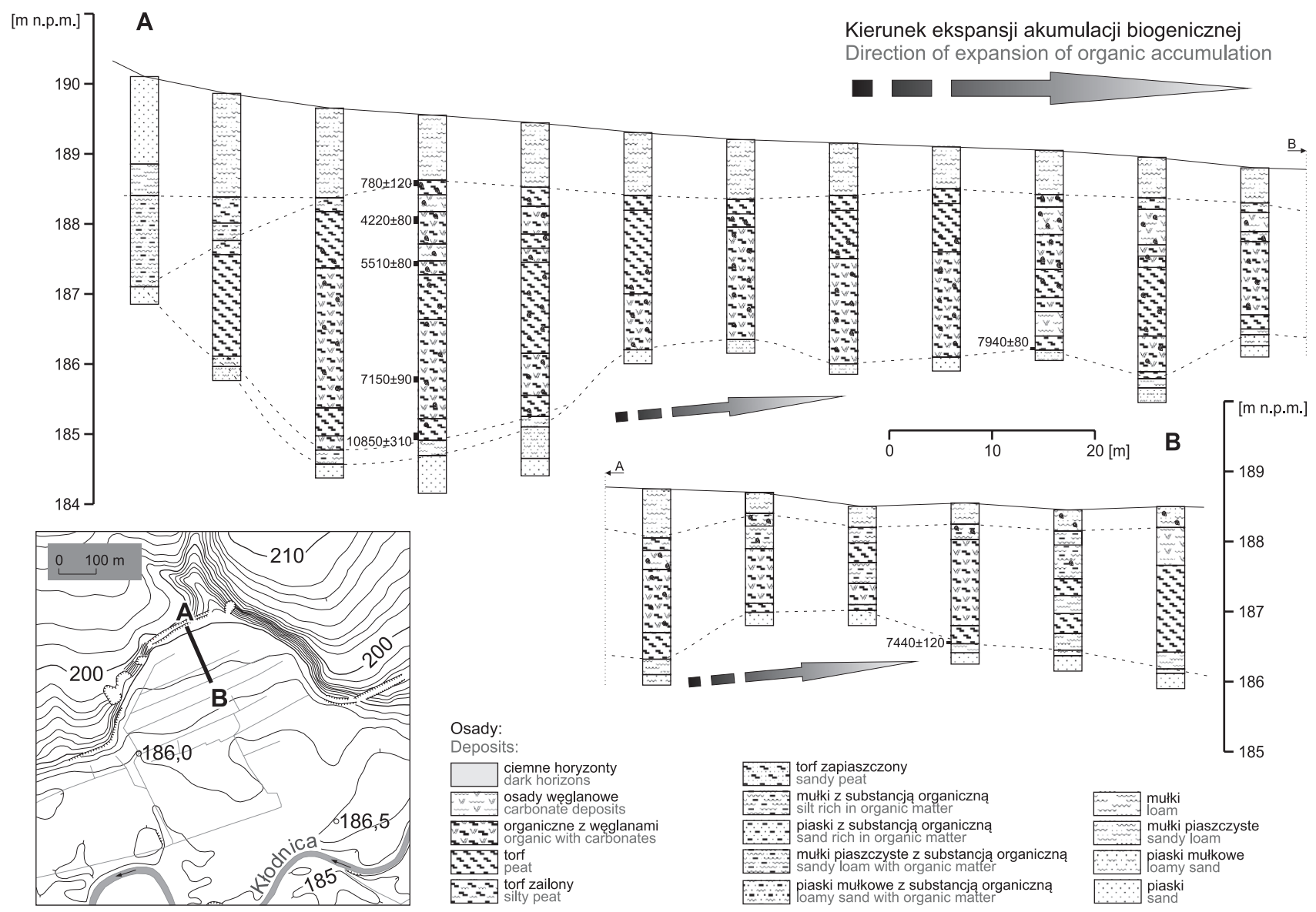

Ryc. 4. Wiek ekspansji procesów akumulacji biogenicznej na przykładzie stanowiska Ujazd/Zandrzyny

Fig. 4. The age of expansion of biogenic accumulation exemplified by the Ujazd/Zandrzyny site

genicznej w dolinach Kłodnicy i Osobłogi koncentrują się w okresie młodszego dryasu i fazy preborealnej holocenu. Taki wiek uzyskano m.in. dla stanowisk Ujazd/ Zandrzyny, Pławniowice, Sławięcice 1 i Sławięcice 2 w dolinie Kłodnicy oraz Głogówek i Żywocice w dolinie Osobłogi. W przypadku mniejszych form położonych w proksymalnej części równiny zalewowej Kłodnicy i Osobłogi akumulacja biogeniczna zainicjowana została w fazie subborealnej (np. stanowisko Las Turbina, Stebłów 1), lub w fazie subatlantyckiej holocenu (stanowiska Stebłów 2 i Krapkowice 2). Wiek inicjacji procesów torfotwórczych w Kotlinie Raciborskiej jest zasadniczo zbieżny z fazami wzmożonego odcinania starorzeczy w dorzeczu górnej Wisły, które przypadają na przełom vistulianu i holocenu oraz neoholocen (por. Szumański 1986, Rutkowski 1987, Starkel i in. 1991, Starkel 2001). Według Kalickiego (2006) zapoczątkowanie zatorfiania doliny Wisły koło Krakowa miało miejsce w pięciu fazach: w okresie preborealnym, na przełomie atlantyku i subboreału, w subboreale (dwie fazy) i starszej części subatlantyku, co znajduje analogie również w dolinach Kłodnicy i Osobłogi.

Wyniki badań z dorzecza górnej Odry wskazują, że zasięg równin torfowiskowych ogranicza się zwykle do depresji starorzeczy. Jednak dość częstym zjawiskiem jest ekspansja procesów torfotwórczych na obszary przyległe do obniżeń paleokoryt. Sytuację taką odnotowano m.in. w przypadku stanowisk Ujazd/Zandrzyny, Sławięcice 2, Głogówek i Żywocice. W świetle rezultatów datowań radiowęglowych (Ryc. 4), torfowisko w stanowisku Ujazd/Zandrzyny założone w późnym visulianie (data $10850 \pm 310$ lat BP w strefie nurtowej) podlegało w fazie atlantyckiej ekspansji wskutek paludyfikacji odsypu meandrowego (daty $7940 \pm 80$ lat BP i $7440 \pm 120$ lat BP uzyskane odpowiednio w odległości 60 i $120 \mathrm{~m} \mathrm{od}$ głównego wiercenia). Analogicznie torfowisko w stanowisku Sławięcice 2, pochodzące ze schyłku glacjału (data $10440 \pm 260$ lat BP w strefie nurtowej) rozszerzyło

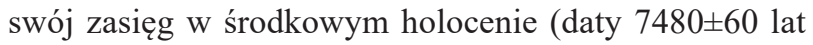
BP i 5550 100 lat BP uzyskane odpowiednio w odległości 13 i $45 \mathrm{~m}$ od głównego rdzenia). Zjawisko ekspansji torfowisk poza „macierzyste” obniżenia starorzeczy nie jest fenomenem obserwowanym wyłącznie w Kotlinie Raciborskiej. Dla przykładu podobną genezę wydaje się mieć torfowisko Słopiec w dolinie Belnianki w Górach Świętokrzyskich (Szczepanek 1982, Ludwikowska-Kędzia 2000).

\section{Przebieg procesów formowania równin akumulacji biogenicznej w holocenie}

Cechą charakterystyczną dla równin akumulacji biogenicznej w dolinie Kłodnicy jest ich trójetapowy rozwój podkreślony zmianami nachylenia krzywej tempa przy- 


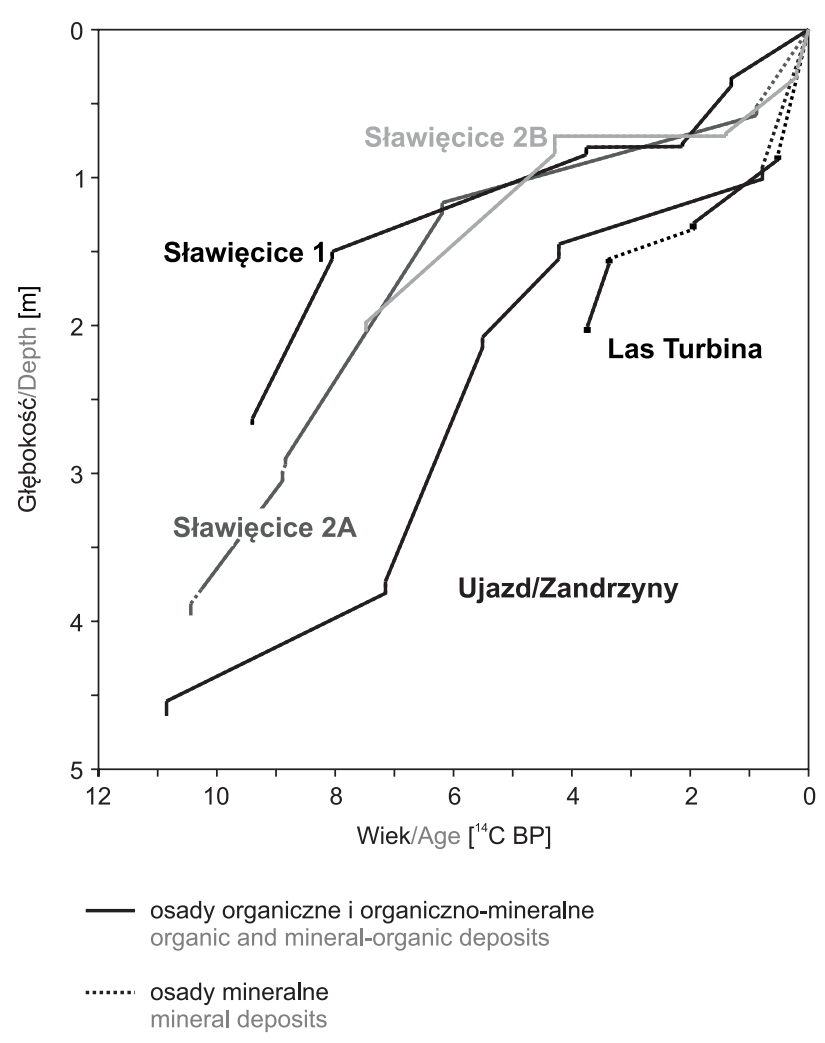

Ryc. 5. Wskaźniki akumulacji dla osadów budujących równiny akumulacji biogenicznej w dolinie Kłodnicy

Fig. 5. Accumulation rates for sediments building organic plains in the Kłodnica River valley

rostu osadów (Ryc. 5). Etap pierwszy cechuje się ponadprzeciętnymi wartościami wskaźnika akumulacji, który sięgnął od 0,36 $\mathrm{mm} \mathrm{a}^{-1} \mathrm{w}$ stanowisku Sławięcice 2 do 0,99 $\mathrm{mm} \mathrm{a}^{-1} \mathrm{w}$ stanowisku Ujazd/Zandrzyny. W zbiornikach akumulacji biogenicznej założonych na przełomie późnego vistulianu i holocenu etap ten przypadał na wczesny i częściowo środkowy holocen, odpowiadając za przyrost około $2 / 3$ miąższości osadów zgromadzonych w poszczególnych profilach. Drugi etap cechowało zahamowanie (hiatusy w stanowiskach Łany Małe, Sławięcice 1 oraz Sławięcice 2), a przynajmniej znaczące ograniczenie tempa przyrostu osadów (np. w stanowisku Las Turbina do $0,34 \mathrm{~mm} \mathrm{a}^{-1}$ ). Należy $\mathrm{w}$ tym miejscu podkreślić, że zapis okresowego przerwania akumulacji biogenicznej lub znaczącego ograniczenia tempa przyrostu torfu w środkowym holocenie zarejestrowano także $w$ innych dolinach południowej Polski. Hiatusy przypadające na fazę atlantycką stwierdzono m.in. w profilach: Nowa Huta (Kalicki, Zernickaya 1995) w dolinie Wisły oraz Słopiec (Szczepanek 1982) i Napęków (Ludwikowska-Kędzia 2000) w dolinie Belnianki. Najmłodszy etap przypadający na młodszą część neoholocenu cechował się ponownym wzrostem wskaźnika akumulacji osadów. W stanowisku Sławięcice 1 tempo przyrostu torfu nie osiągnęło tak wysokich wartości, jak w najstarszej fazie $(0,48 \mathrm{~mm}$ $\mathrm{a}^{-1} \mathrm{w}$ stosunku do $\left.0,65 \mathrm{~mm} \mathrm{a}^{-1}\right)$, natomiast $\mathrm{w}$ stanowisku Sławięcice 2 w strefie odsypu meandrowego (profil Sławięcice 2B) to osady najmłodszej fazy przyrastały najszybciej $\left(0,36-1,22 \mathrm{~mm} \mathrm{a}^{-1}\right)$. Przyczyn wahań tempa

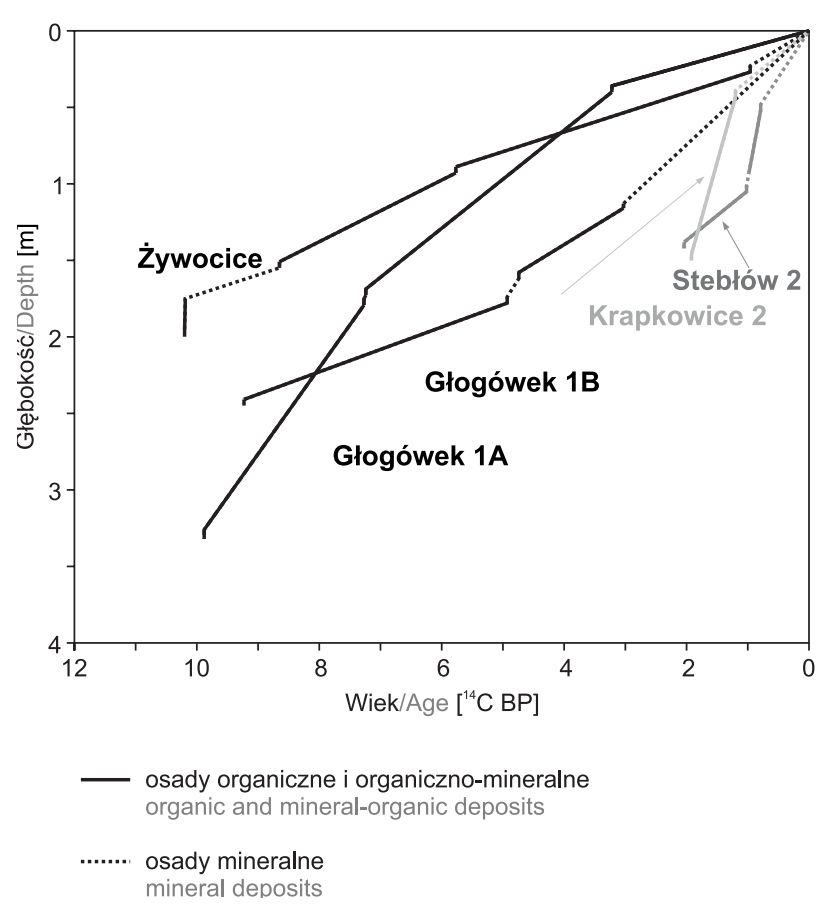

Ryc. 6. Wskaźniki akumulacji dla osadów budujących równiny akumulacji biogenicznej w dolinie Osobłogi

Fig. 6. Accumulation rates for sediments building organic plains in the Osobłoga River valley

akumulacji biogenicznej należy dopatrywać się w zmianach stosunków hydrologicznych na torfowiskach, w ślad za którymi podążały zmiany zbiorowisk torfotwórczych (Wójcicki 2013). Zmiany te miały zasięg lokalny. W stanowiskach z doliny Osobłogi nie zidentyfikowano skokowego obniżenia wartości wskaźnika akumulacji na przełomie środkowego i młodszego holocenu (Ryc. 6), tak charakterystycznego dla profili z doliny Kłodnicy. Najbardziej prawdopodobną przyczyną tego zróżnicowania jest nakładanie się czynników endogenicznych (szybszy przyrost osadów w początkowych fazach rozwoju starorzeczy - wolniejszy po zlądowaceniu) i egzogenicznych (ograniczenie akumulacji organicznej w warunkach słabszego zasilania wodami opadowymi, napływowymi lub gruntowymi). Wzajemny układ tych czynników mógł decydować o lokalnym zróżnicowaniu warunków zasilania poszczególnych torfowisk.

W budowie wewnętrznej form akumulacji biogenicznej zapisane są epizody przerwania ich rozwoju w następstwie dostawy utworów mineralnych przez procesy fluwialne lub w wyniku spłukiwania ze stoku. Datowania radiowęglowe wskazują, że przerwanie akumulacji biogenicznej mogło być relatywnie krótkotrwałe, obejmując okres rzędu kilkudziesięciu lat (jak w profilu Sławięcice $2 \mathrm{~A}$, gdzie sedymentacja piaszczystej warstwy na głębokości 294-299 cm jest datowana pomiędzy $8890 \pm 150$ a $8840 \pm 150{ }^{14} \mathrm{C}$ lat BP) lub dhugotrwałe - mierzone w setkach lub tysiącach lat (jak w stanowiskach Głogówek między $4930 \pm 70$ a $4740 \pm 70$, Las Turbina między $3370 \pm 60$

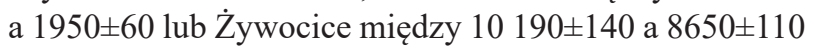
${ }^{14} \mathrm{C}$ lat BP). Po ustąpieniu przyczyn wzmożonej depozycji mineralnej na badanych mokradłach zazwyczaj wznawia- 
na była akumulacja organiczna. Dopiero wzbudzona antropogenicznie, intensywna akumulacja mineralna zapoczątkowana we wczesnym średniowieczu (m.in. Klimek 1996, 2003, Wójcicki, Marynowski 2012), doprowadziła w niektórych stanowiskach do trwałego przerwania akumulacji organicznej. Do całkowitego przykrycia równin akumulacji biogenicznej osadami mineralnymi doszło w stanowiskach Ujazd/Zandrzyny (progradacja stożka napływowego pomiędzy $2240 \pm 100$ a $780 \pm 120{ }^{14} \mathrm{C}$ lat BP (Klimek, 2003)), Łany Małe $\left(1720 \pm 80{ }^{14} \mathrm{C}\right.$ lat BP), Huta Piła $\left(1215 \pm 70{ }^{14} \mathrm{C}\right.$ lat BP), Krapkowice $2\left(1200 \pm 50{ }^{14} \mathrm{C}\right.$ lat BP), Stebłów $2\left(790 \pm 60{ }^{14} \mathrm{C}\right.$ lat BP) oraz Las Turbina $\left(520 \pm 60{ }^{14} \mathrm{C}\right.$ lat BP). Do częściowego pogrzebania form akumulacji organicznej od strony stoków doliny doszło m.in. w stanowiskach Sławięcice $1\left(1305 \pm 70{ }^{14} \mathrm{C}\right.$ lat BP), Sławięcice 2 (pomiędzy $880 \pm 60$ a $200 \pm 60{ }^{14} \mathrm{C}$ lat BP), Las Czajka $\left({ }^{14} \mathrm{C}\right.$ lat BP $\left.720 \pm 60\right) \mathrm{w}$ dolinie Kłodnicy oraz Krapkowice $1\left(1340 \pm 50^{14} \mathrm{C}\right.$ lat BP) i Żywocice $(960 \pm 60$ ${ }^{14} \mathrm{C}$ lat BP) w dolinie Osobłogi.

\section{Wnioski}

1. Równiny akumulacji biogenicznej w dolinach rzecznych strefy „staroglacjalnej” południowej Polski powstają najczęściej w obniżeniach starorzeczy. Formy te cechują się niewielkimi rozmiarami (zwykle $<5$ ha) i mimo swej dużej liczby zajmują łącznie niewielki obszar - w dorzeczu górnej Odry nie przekraczający kilku procent powierzchni den dolinnych. Równiny akumulacji biogenicznej spotykane są zwykle w dystalnej, przyzboczowej części dolin. Występujące tam, korzystne warunki związane z soligenicznym typem zasilania umożliwiają ekspansję procesu paludyfikacji poza macierzyste obniżenia starorzeczy. Formy akumulacji biogenicznej w strefie proksymalnej równin zalewowych mają gorsze warunki rozwoju z uwagi na silniejsze oddziaływanie erozji i depozycji fluwialnej oraz większe uzależnienie od efemerycznego zasilania fluwiogenicznego.

2. Procesy akumulacji biogenicznej w starorzeczach Kłodnicy i Osobłogi inicjowane były w różnych fazach późnego vistulianu i holocenu, ale z preferencją dla dwóch okresów: młodszego dryasu i fazy preborealnej (formy akumulacji biogenicznej w położeniu podstokowym) oraz fazy subborealnej i subatlantyckiej (małe formy w osi doliny).

3. Tempo rozwoju form akumulacji biogenicznej uzależnione było od lokalnych warunków zasilania, zmieniających się pod wpływem czynników endogenicznych (fazy rozwojowej zbiornika akumulacji biogenicznej) oraz egzogenicznych (m.in. warunków klimatycznych). W dolinie Kłodnicy, pod wpływem korzystnego układu tych czynników nastąpił szybki rozwój równin akumulacji biogenicznej w starszym i środkowym holocenie oraz regres ich rozwoju na przełomie mezo- i neoholocenu. W dolinie Osobłogi tempo przyrostu osadów równin akumulacji bioge- nicznej było raczej niskie i dość jednostajne przez cały holocen.

4. Począwszy od wczesnego średniowiecza, w warunkach antropogenicznego ożywienia procesów fluwialnych i denudacyjnych liczba aktywnych form akumulacji biogenicznej w dolinach Kłodnicy i Osobłogi uległa wydatnemu zmniejszeniu.

\section{Literatura}

Alexandrowicz S.W., Klimek K., Kowalkowski A., Mamakowa K., Niedziałkowska E., Pazdur M., Starkel L., 1981. The evolution of the Wisłoka valley near Dębica during the Late Glacial and Holocene. Folia Quaternaria 53: 3-91.

Gębica P., 2004. Przebieg akumulacji rzecznej w górnym vistulianie w Kotlinie Sandomierskiej. Prace Geograficzne 193: 1-229.

Ilnicki P., 2002. Torfowiska i torf. Wydawnictwo Akademii Rolniczej, Poznań.

Kalicki T., 2006. Zapis zmian klimatu oraz działalności człowieka i ich rola $\mathrm{w}$ holoceńskiej ewolucji dolin środkowoeuropejskich. Prace Geograficzne 204: 5-348.

Kalicki T., Zernickaya V.P., 1995. Paleogeography of the Vistula valley near Cracow based on sediments and palynology of the Allerød paleochannel fill. In: Starkel L. (ed.) Evolution of the Vistula River valley during the last 15000 years. Part V. Geographical Studies, Special Issue 8: 9-18.

Klimek K., 1996. Aluwia Rudy jako wskaźnik 1000-letniej degradacji Płaskowyżu Rybnickiego. w: Kostrzewski A. (red.) Geneza, litologia i stratygrafia utworów czwartorzędowych, tom II. Wyd. UAM, Poznań: 155-166.

Klimek K., 2003. Sediment transfer and storage linked to Neolithic and Early Medieval soil erosion in the Upper Odra Basin, southern Poland. In: Howard A.J., Macklin M.G., Passmore D.G. (eds) Alluvial Archaeology in Europe. Swets \& Zeitlinger, Lisse: 251-259.

Krygowski B., 1936. Basen Jeziora Zasumińskiego jako przykład basenu wydmowo-bagiennego. Wiadomości Służby Geograficznej 4: 466-478.

Kulczyński S., 1939-40. Torfowiska Polesia. Prace Rolniczo-Leśne PAU 37(1/2): s. 777.

Ludwikowska-Kędzia M., 2000. Ewolucja środkowego odcinka doliny rzeki Belnianki w późnym glacjale i holocenie. Wydawnictwo Akademickie Dialog, Warszawa: 5-181.

Małkowski S., 1930. Uwagi w sprawie zabagnienia Polesia. Pos. Nauk. PIG 28: 14-16.

Nalepka D., 1991. Lateglacial end Early Holocene pollen diagrams in the western part of the Sandomierz Basin. Preliminary results. In: Evolution of the Vistula river valley during the last 15000 years, part IV. Geographical Studies, Special Issue 6: 63-74.

Nita M., Wójcicki K., 2005. Record of Holocene vegetation changes against a background of environmental conditions in the Kłodnica valley (southern Poland). Quaestiones Geographicae 24: 63-73.

Rutkowski J., 1987. Vistula River valley in the Cracow Gate during the Holocene. In: Evolution of the Vistula river valley during the last 15000 years, part II. Geographical Studies, Special Issue 4: 31-49.

Schubert C., 1930. Pollenanalytische Untersuchungen im Wiegschützer Moor. Der Oberschlesier 12: 435-440.

Starkel L., 2001. Historia doliny Wisły od ostatniego zlodowacenia do dziś. Monografie IGiPZ PAN, Warszawa: 5-263.

Starkel L., Gębica P., Niedziałkowska E., Podgórska-Tkacz A., 1991. Vistula floodplain and Lateglacial-early Holocene palaeochannel systems in the Grobla Forest. In: Evolution of the Vistula river valley during the last 15000 years, part IV. Geographical Studies, Special Issue 6: 87-99.

System Informacji Przestrzennej o Mokradłach Polski, 2006. Instytut Melioracji i Użytków Zielonych, Falenty.

Szczepanek K., 1982. Development of the peat-bog at Słopiec and the vegetational history of the Świętokrzyskie (Holy Cross) Mts in the last 10000 years. Acta Palaeobotanica 22(1): 117-130. 
Szumański A., 1986. Postglacjalna ewolucja i mechanizm transformacji dna doliny Dolnego Sanu. Geologia 12(1): 5-89.

Wasylikowa K., Starkel L., Niedziałkowska E., Skiba S., Stworzewicz E., 1985. Environmental changes in the Vistula valley at Pleszów caused by Neolithic man. Przegląd Archeologiczny 33: 19-55.

Wójcicki K.J., 2006. The oxbow sedimentary subenvironment: its value in palaeogeographical studies as illustrated by selected fluvial systems in the Upper Odra catchment, southern Poland. The Holocene 16(4): 589-603.

Wójcicki, K.J., 2010. Pochodzenie oraz antropogeniczne przeobrażenia krajobrazów torfowiskowych w dolinie Kłodnicy. w: J. Plit (red.), Krajobrazy kulturowe dolin rzecznych. Potencjał i wykorzystanie. Prace Komisji Krajobrazu Kulturowego PTG 13: 122-134.

Wójcicki K.J., 2012. Stratigraphy of organic-rich deposits in floodplain environments: examples from the upper Odra River basin. Quaestiones Geographicae 31(3): 107-117.
Wójcicki K.J., 2013. Osady biogeniczne w środowisku depozycyjnym starorzeczy (warunki akumulacji i wymowa paleośrodowiskowa na przykładach z dorzecza górnej Odry). Wydawnictwo Uniwersytetu Śląskiego, Katowice: 5-239.

Wójcicki K.J., Kloss M., 2008. Makroszczątki roślinne w torfie w analizie paleośrodowiskowych uwarunkowań osadnictwa na przykładzie stanowiska Łany Małe w dolinie Kłodnicy. Studia Ecologiae et Bioethicae 6: 449-460.

Wójcicki K.J., Marynowski L., 2012. The content of organic and mineral matter in deposits infilling floodplain basins; Holocene alluviation record from the Rivers Kłodnica and Osobłoga valleys, southern Poland. Geomorphology 159-160: 15-29.

Zygmunt E, 2004. Archaeological and radiocarbon dating of alluvial fans as an indicator of prehistoric colonisation of the Głubczyce Plateau (southwestern Poland). Geochronometria 23: 101-107.

Żurek S., 1975. Geneza zabagnienia Pradoliny Biebrzy. Prace Geograficzne PAN IGiPZ 110: 1-107. 